\title{
Low Concentrations of Interferon-gamma Stimulate DNA Synthesis in Normal Human Keratinocytes during the Initial Stages of Cultivation
}

\author{
KEIJI OKUBO, TADASHI KARASHIMA, HIROSHI HACHISUKA \\ AND YOICHIRO SASAI \\ Department of Dermatology, Kurume University School of Medicine, Kurume, 830 Japan
}

Received for publication January 9, 1991

\begin{abstract}
Summary: High concentrations of interferons can inhibit keratinocyte proliferation and induce the expression of HLA-DR antigen on keratinocytes. In the present study, the effects of low concentrations of recombinant human interferon $\alpha, \beta$ and $\gamma$ were examined on DNA synthesis and the expression of HLA-DR and bullous pemphigoid (BP) antigens in normal human keratinocytes. Low concentrations of interferons induced DNA synthesis in normal human keratinocytes when epidermal cell growth factor and low $\mathrm{Ca}^{++}$ were used during the initial stages of culturing. This result indicates that physiological concentrations of interferons can induce keratinocyte activation.
\end{abstract}

Key words: keratinocyte - Interferon-gamma-DNA synthesis-BP antigen - HLA-DR antigen

\section{Introduction}

Interferons (IFNs), initially described as antiviral factors (Isaacs and Lindemann, 1957), have many effects on cellular function. IFNs inhibit cell multiplication both in vivo and in vitro (Ho, 1982) and can affect a wide range of immunomodulatory functions (Blalock et al. 1980). In the skin, the evidence for an important role of IFN- $\gamma$ in immune phenomena of the human keratinocyte is indicated by the induced expression of HLA-DR antigen. IFN- $\gamma$ is produced by activated $\mathrm{T}$ lymphocytes (Barker et al. 1988), and HLA-DR antigen has been shown to be expressed on the keratinocytes in a variety of dermatological diseases characterized by an activated $\mathrm{T}$-cell infiltrate, such as lichen planus (Tjernlund, 1980) and contact dermatitis (Mackie and
Turbitt, 1983).

High concentrations of IFNs are not detected physiologically, in vivo. Although previous studies have described high concentrations of IFNs as inhibitory factors in normal keratinocyte growth (Yaar et al. 1985) and in malignant squamous cell lines (Nickoloff et al. 1985), the effects of physiologically low concentrations of IFNs on the normal human keratinocyte have not been described in detail.

In this study, the effects of low concentrations of IFNs on the expression of HLA-DR and bullous pemphigoid (BP) antigens and DNA synthesis of normal human keratinocytes in vitro are reported and the physiological roles for IFNs in interacting with human keratinocytes and thereby modifying immunological reactions of the skin are discussed.

Reprint requests to: Hiroshi Hachisuka, M.D., Department of Dermatology, Kurume University School of Medicine, 67 Asahimachi, Kurume, 830 Japan. 


\section{Materials and Methods}

\section{Human Keratinocyte Culture}

Normal human epidermal keratinocytes (NHEK, Clonectics, San Diego, CA) were used in these experiments. Cells were grown in a serum-free keratinocyte growth medium (KGM, Clonectics). KGM consisted of MGDB 153 medium with epidermal growth factor (EGF), insulin, hydrocortisone, bovine pituitary extract protein, and $0.1 \mathrm{mM}$ calcium. In this medium, NHEK cells grew well and were suitable for studies of normal human keratinocyte growth and differentiation (Pillai et al. 1988). At 90\% confluence, keratinocytes were trypsinized $(0.025 \%$ trypsin/0.01\% EDTA, EpiPack, Clonectics) to a single cell suspension, washed in trypsin neutralizing solution (EpiPack), and seeded in 96 -well microculture plates (Costar, Cambridge, MA) for the DNA synthesis assay, and in 24-well plates (Costar) for the FACS analysis. As a control, EMEM cell culture medium (GIBCO, Grand Island, NY) with 10\% FCS (GIBCO) and $1.3 \mathrm{mM}$ calcium (high calcium) was used.

\section{In Vitro Keratinocyte DNA Synthesis Assay}

Keratinocytes were seeded at $5 \times 10^{3}$ cells per well in $0.2 \mathrm{ml}$ of $\mathrm{KGM}$, and cultured overnight in humidified air containing $5 \% \mathrm{CO}_{2}$. Non-adherent keratinocytes were removed, and $0.2 \mathrm{ml}$ of $\mathrm{KGM}$ with or without recombinant IFNs was added to each well. After $44-140 \mathrm{hr}$ of culture, $1 \mu \mathrm{Ci}$ of $\left[{ }^{3} \mathrm{H}\right]$-thymidine (New England Nuclear, Boston, MA) was added to each well and the culture was continued for an additional $4 \mathrm{hr}$. After treating with $0.025 \%$ trypsin for $10 \mathrm{~min}$, cells were harvested and washed using an automatic cell harvester (LABO MASH, Labo Science, Tokyo, Japan). The $\left[{ }^{3} \mathrm{H}\right]$ thymidine content was determined with a liquid scintillation counter (LSC 1000, ALOKA, Tokyo, Japan).

\section{Cytokines}

Human recombinant IFN- $\gamma$ was obtained from Takeda Chemical Industry (Osaka, Japan), and IFN- $\alpha$ and IFN- $\beta$ from Kyowa Hakko (Tokyo, Japan). All IFNs were diluted with KGM.

Inhibition of IFN-y induced DNA Synthesis by Anti-IFN-r Antibodies

Rabbit anti-human IFN- $\gamma$ polyclonal antiserum (Genzyme, Boston, MA) was used for this assay. The antiserum was dialyzed with KGM to remove sodium azide. The resulting antiserum was not cytotoxic for NHEK cells. $\left[{ }^{3} \mathrm{H}\right]$-thymidine incorporation was measured at $96 \mathrm{hr}$ of cultivation after adding IFN- $\gamma$ (1-100U) and antiserum $\left(1: 10^{-1}: 1,000\right)$.

\section{Flow cytometry analysis}

$5 \times 10^{5}$ cells per well were seeded in 24 well plates (Costar) and cultured overnight to permit cell adherence. Various concentrations of IFNs were added to the wells and the cultures were continued for $96 \mathrm{hr}$. After $0.025 \%$ trypsin treatment for $10 \mathrm{~min}$, the cells were washed in phosphate buffered saline (PBS, pH 7.4, $0.15 \mathrm{M})$, and stained with FITC-conjugated anti-HLA-DR monoclonal antibody (Becton-Dickinson, Mountainview, CA). For demonstrating the expression of bullous pemphigoid (BP) antigen, cells were incubated with the anti-BP antigen antiserum which was obtained from a BP patient. Fluorescein conjugated rabbit immunoglobins to human IgG (DAKO, Glostrup, Denmark) were used as secondary antibodies. 10,000 cells were analyzed by laser flow cytometry (Cytoron, Ortho Japan, Tokyo) (Okubo et al. 1989).

\section{Statistical analysis}

For the statistical analysis of $\left[{ }^{3} \mathrm{H}\right]$. thymidine incorporation into NHEK cells, the Student $t$-test was used. The results were considered statistically significant 
when the $\mathrm{p}$ value was less than 0.05 .

\section{Results}

Effect of IFNs on DNA synthesis of NHEK cells

Although the NHEK cells synthesized some DNA in the initial $48 \mathrm{hr}$ of cultivation in either EMEM containing 10\% FCS (high calcium medium) or in KGM lacking EGF (Fig. 1A), these cells could not continue to synthesize DNA after $96 \mathrm{hr}$ of cultivation (Fig. 1A). IFN- $\alpha$ did not enhance the DNA synthesis of the NHEK cells under these conditions (Fig. 1A). In KGM containing EGF, the NHEK cells incorporated $\left[{ }^{3} \mathrm{H}\right]$-thymidine, as measured after 48 and $96 \mathrm{hr}$ of cultivation (Fig. 1B). However, after $144 \mathrm{hr}$ the NHEK cells no longer incorporated $\left[{ }^{3} \mathrm{H}\right]$ thymidine (Fig. 1B). $\left[{ }^{3} \mathrm{H}\right]$-thymidine incorporation was increased by treatment with $500 \mathrm{U}$ of IFN $-\alpha$ at $96 \mathrm{hr}$ of cultivation (Fig. 1B). IFN- $\beta$ at concentrations between $100 \mathrm{U}$ and $1,000 \mathrm{U}$ (Fig. 1C) and IFN $-\gamma$ between $10 \mathrm{U}$ and 500U (Fig. 1D) enhanced DNA synthesis in the NHEK cells after $96 \mathrm{hr}$ of cultivation in KGM containing EFG. Although the IFNs did not induce DNA synthesis after $144 \mathrm{hr}$ of cultivation (Fig. 1), the NHEK cells did not become confluent. The number of NHEK cells did not change in IFNtreated or nontreated groups as judged by microscopic cell counts (data not shown).
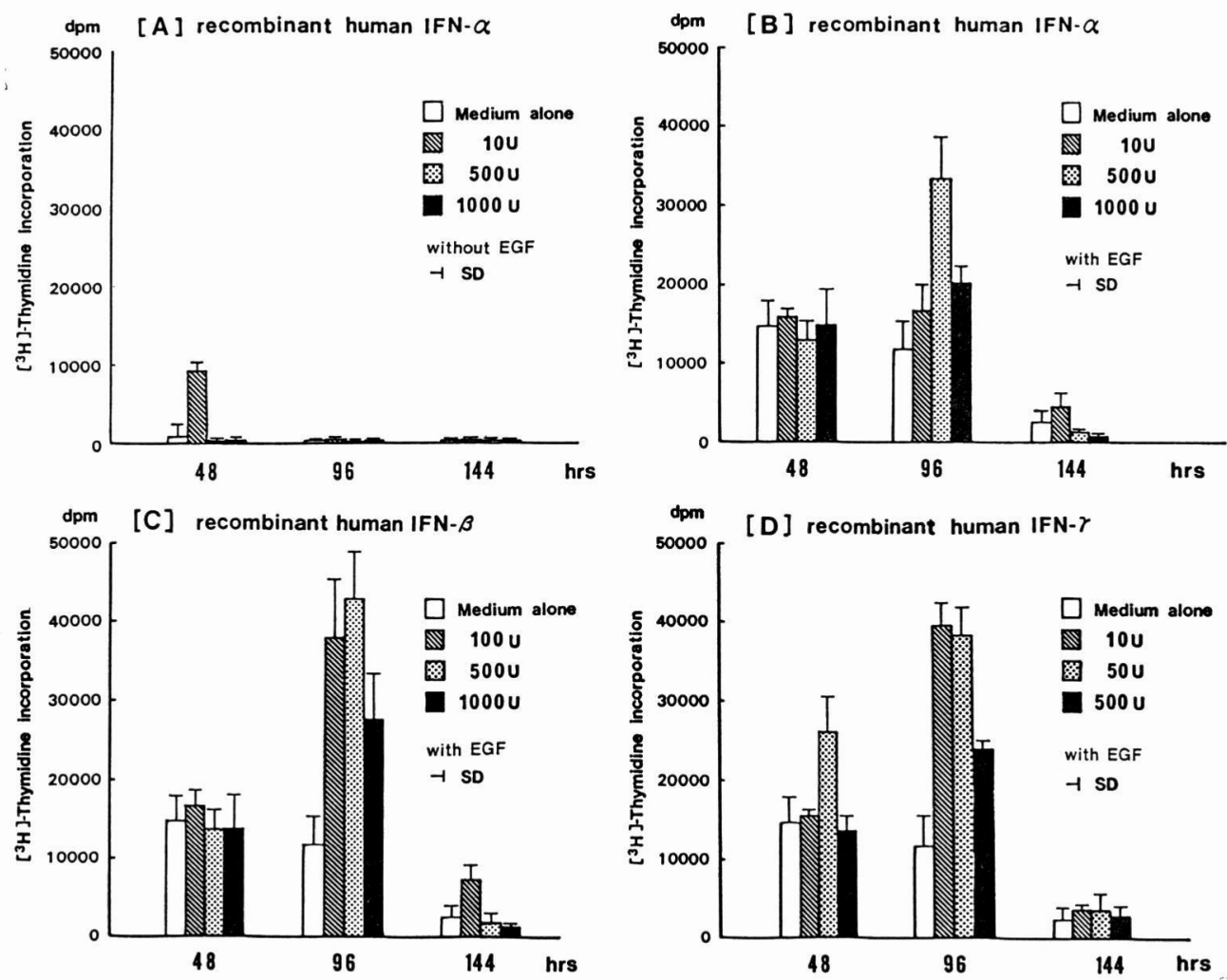

Fig. 1. The effects of interferon $\alpha, \beta$ and $\gamma$ on $\left[{ }^{3} \mathrm{H}\right]$ thymidine incorporation into NHEK $18-1$ cells. 


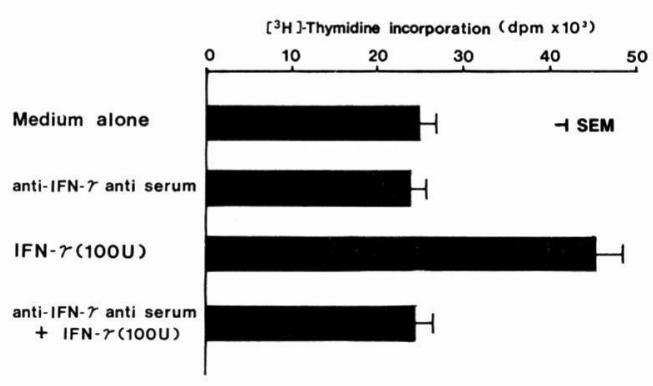

Fig. 2. A blocking test on DNA synthesis in NHEK 18-1 cells by treatment with rabbit anti-human interferon $\gamma$.

\section{BP antigen}

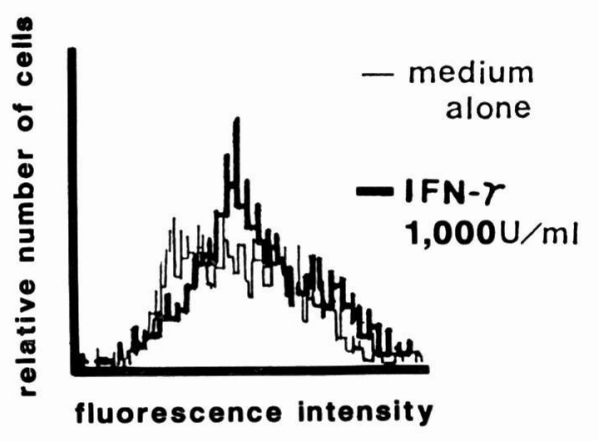

HLA-DR antigen

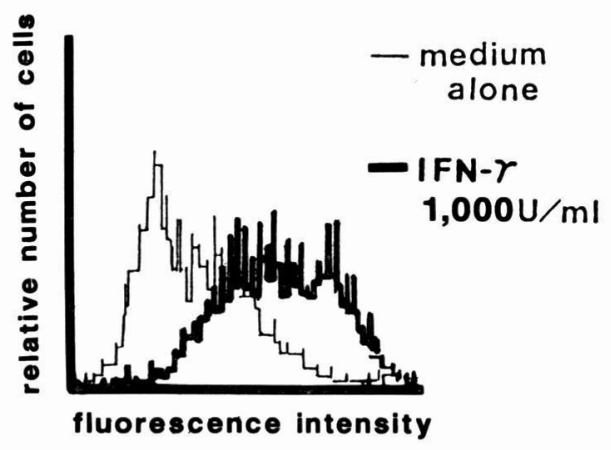

Fig. 3. Induction of the expression of BP and HLA-DR antigens on NHEK 18-1 cells.
Blockade of DNA synthesis in NHEK cells using rabbit anti-human interferon antiserum

With rabbit anti-human IFN- $\gamma$ antiserum, it was possible to determine whether the effect of IFN- $\gamma$ on DNA synthesis in NHEK cells was inhibited after $96 \mathrm{hr}$ of cultivation. $\left[{ }^{3} \mathrm{H}\right]$-thymidine incorporation into NHEK cells was not influenced by the addition of the anti-human IFN- $\gamma$ antiserum, as compared with NHEK cells cultured in KGM alone. As shown in Fig. 2, the enhancement of $\left[{ }^{3} \mathrm{H}\right]$ thymidine incorporation in NHEK cells induced by IFN- $\gamma$ was completely blocked by anti-human IFN- $\gamma$.

Induction of the expression of BP and HLA$D R$ antigens on NHEK cells by IFNs

The histogram patterns of fluorescence intensity of $\mathrm{BP}$ and HLA-DR antigens are shown in Fig. 3. The fluorescence intensity was increased by the application of $1,000 \mathrm{U}$ of recombinant human IFN $-\gamma$. However, low concentrations of IFN- $\gamma$ could not induce the expression of HLADR and BP antigens (data not shown). On the other hand, IFN- $\alpha$ or IFN- $\beta$ at any concentration did not enhance the expression of $\mathrm{BP}$ and HLA-DR antigens on NHEK cells (data not shown).

\section{Discussion}

It has been reported that IFNs are inhibitory for keratinocyte proliferation in long term cultivations (Nickoloff et al. 1985; Yaar et al. 1985). In this study, IFN- $\alpha$, IFN- $\beta$ and IFN- $\gamma$ enhanced $\left[{ }^{3} \mathrm{H}\right]$ thymidine incorporation into DNA synthesis in normal human keratinocytes at early stages of cultures in KGM with low calcium (Fig. 1). In particular, it is important that low concentration of $\mathrm{IFN}_{-\gamma} \gamma$ (10U) could enhance DNA synthesis during the initial stage of cultivation with a low calcium EGF medium. NHEK cells 
did not react with IFNs in EMEM with high calcium or in KGM without EGF. With long term cultivated keratinocytes or confluent NHEK cells, these effect of IFNs were not observed (data not shown). At high concentrations of IFNs, only IFN- $\gamma$, and not IFN- $\alpha$ or IFN- $\beta$, induced the expression of HLA-DR antigen and $\mathrm{BP}$ antigen on normal human keratinocytes. Low concentrations of IFN- $\gamma$ could not induce the expression of BP and HLA$\mathrm{DR}$ antigens on human keratinocytes.

HLA-DR antigen is defined as a human Class II molecule encoded by genes within the major histocompatibility complex, and this antigen is expressed on activated $\mathrm{T}$ lymphocytes (Yachie et al. 1983) and macrophages treated with IFN- $\gamma$ (Littman et al. 1989). Epidermal keratinocytes show expression of the HLA-DR antigen in certain disease states, such as graft-versus-host disease and lichen planus (Tjernlund, 1978; Lampert et al. 1981). High concentrations of IFN- $\gamma$ induce HLA-DR antigen on cultured human keratinocytes (Wikner et al. 1986) and injection of high doses of IFN- $\gamma$ can induce murine keratinocyte expression of Ia antigen of the mouse class II molecule in vivo (Jun et al. 1989). Although it has been reported that the main role of IFNs may be an antiproliferative effect on keratinocyte growth (Nickoloff et al. 1985; Yaar et al. 1985), IFN-y can induce new protein production in cultured human keratinocytes and expression of HLA-DR antigens on keratinocytes (Mansbridge et al. 1987). The IFNs did not play a major role in the control of keratinocyte behavior. Streilein (1983) has proposed the existence of an immunological system in epidermis, which he termed SALT (skin associated lymphoid tissue). It is a system of immune surveillance based on a correlation between the epidermis and lymph nodes. However, immunological roles of keratinocytes are still not defined in this concept. Nickoloff et al. (1986) recently observed that cultured human keratinocytes induce activation of $T$ cells and that the intercellular adhesion molecule-1 (ICAM-1) is implicated in epidermal- $T$ cell communication by its affinity for lymphocyte function associated antigen-1 (LFA-1). These molecules are important in cell attachment (Marlin and Springen, 1987). ICAM-1 is expressed on keratinocytes derived from patients with psoriasis but the expression of HLA-DR antigen appears to have no strong correlation with disease severity (Lisby et al. 1989). IFN- $\gamma$ induces ICAM-1 and HLA-DR expression on keratinocytes (Griffiths et al. 1989), and enhances the binding of peripheral blood $\mathrm{T}$ lymphocytes to human keratinocytes (Nickoloff and Griffiths, 1989).

In this study, IFNs enhanced DNA synthesis during the initial stages of cultivation. In particular, the fact that a low concentration of IFN- $\gamma$ can enhance DNA synthesis in normal human keratinocytes in low calcium and the existence of EGF are very important when the roles of IFN- $\gamma$ in human physiological status are considered. The expression of HLA-DR and BP antigens on human keratinocytes was induced by high concentrations of IFN- $\gamma$. On the other hand, low concentrations of IFN- $\alpha$ and IFN- $\beta$ could not enhance DNA synthesis and induce the expression of BP and HLA-DR antigens during the early stages of human keratinocyte cultivation. BP antigens of various molecular weights are expressed by normal human cultured keratinocytes (Su et al. 1989) and the amount of BP antigen is enhanced by a high dose of IFN-y (Sugita et al. 1988). Inasmuch as any amount of IFN, except high concentrations of IFN- $\gamma$, could not induce the expression of BP and HLA-DR antigens on normal human keratinocytes, it is difficult to explain the role of physiological concentrations of IFNs on the expressions of both antigens. However, 
it is important that low concentrations of IFN- $\gamma$ enhanced DNA synthesis in normal human keratinocytes during the initial stages of cultivation when IFNs may have a role in physiological status. The phenomena of class II antigen expression and DNA synthesis on keratinocyte activation were induced by IFN- $\gamma$. Furthermore intradermal injection of IFN- $\gamma$ induced human keratinocytes to express ICAM-1 and favor attachment of $T$ cells in the basement membrane zone (Barker et al. 1989). Therefore, we suggest that IFN- $\gamma$ activates both $\mathrm{T}$ lymphocytes and keratinocytes in inflammatory skin, and IFN- $\gamma$ activated keratinocytes may have important immunological roles in the communication between the epidermis and various immune cells.

Acknowledgment: The authors would like to thank Dr. Geoffrey Rowden (Dalhousie University) for reviewing this manuscript.

\section{Reference}

Barker, J.N.W.N., Navsaria, H. A., Leigh, I. M. and MacDonald, D.M. (1988). Gamma-interferon induced human keratinocyte HLA-DR synthesis: The role of dermal activated $T$ lymphocytes. Br. J. Dermatol. 119, 567-572.

Barker, J.N.W.N., Allen, M.H. and MacDonald, D.M. (1989). The effect of in vivo interferon-gamma on the distribution of LFA-1 and ICAM-1 in normal human skin. J. Invest. Dermatol. 93, 437-442.

Blalock, J.E., Georgiades, J. A., Langford, M.P. and Johnson, H.M. (1980). Purified human immune interferon has more potent anticellular activity than fibroblast or leukocyte interferon. Cell. Immunol. 49, 390-394.

Griffiths, C.E.M., VoorheEs, J. J. and Nickoloff, B. J. (1989). Characterization of intercellular adhesion molecule-1 and HLA-DR expression on normal and inflamed skin: Modulation by recombinant gamma interferon and tumor necrosis factor. J. Am. Acad. Dermatol. 20, 617-629.

Ho, M. (1982). Recent advances in the study of interferon. Pharmacol. Rev. 34, 119-129.
IsaAcs, A. and Lindenmann, J. (1957). Virus interference I. The interferons. Proc. R. Soc. Lond. [Biol] 147, 258-267.

Jun, B.D., Krueger, G.G. and Roberts, L.K. (1989). Differential expression of Ia by murine keratinocytes and gut epithelium in response to recombinant gamma-interferon. J. Invest. Dermatol. 93, 33-39.

Lampert, I.A., Suitters, A.J. and Chisholm, P.M. (1981). Expression of Ia antigen on epidermal keratinocytes in graft-versus-host disease. Nature 293, 149-150.

Lisby, S., Ralfkiaer, E., Rothlein, R. and VeJLSGAARD, G.L. (1989). Intercellular adhesion molecuie-1 (ICAM-1) expression correlated to inflammation. Br. J. Dermatol. 120, 479-484.

Littman, B. H., Dastvan, F.F., Carlson, P.L. and SANDERS, K.M. (1989). Regulation of monocyte/macrophage $\mathrm{C} 2$ production and HLA-DR expression by IL-4 (BSF-1) and IFN-gamma. J. Immunol. 142, 520-525.

Mackie, R.M. and Turbitt, M.L. (1983). Quantitation of dendritic cells in normal and abnormal human epidermis using monoclonal antibodies directed against Ia and HLA antigens. J. Invest. Dermatol. 81, 216-220.

Mansbridge, J. N., Nickoloff, B. J. and Morhenn, V.B. (1987). Induction of new proteins by gamma interferon in cultured human keratinocytes. J. Invest. Dermatol. 88, 602-610.

Marlin, S. D. and Springen, T.A. (1987). Purified intercellular adhesion molecule-1 (ICAM-1) is a ligand for lymphocyte function associated antigen 1 (LFA-1). Cell 51, 813-819.

Nickoloff, B. J., Basham, T.Y., Merigan, T.C. and MorhenN, V.B. (1985). Immunomodulatory and antiproliferative effect of recombinant alpha, beta, and gamma interferons on cultured human malignant squamous cell lines, SCL-1 and SW-1271. J. Invest. Dermatol. 84, 487-490.

Nickoloff, B.J., Basham, T.Y., Merigan, T.C., Torseth, J.W. and Morhenn, V.B. (1986). Human keratinocyte-lymphocyte reactions in vitro. J. Invest. Dermatol. 87, 11-18.

Nickoloff, B.J. and Griffiths, C.E.M. (1989). $\mathrm{T}$ lymphocytes and monocytes bind to keratinocytes in frozen sections of biopsy specimens of normal skin treated with gamma interferon. J. Am. Acad. Dermatol. 20, 736-743. 
Pillai, S., Bikle, D.D., Hincenbergs, M. and Elias, P.M. (1988). Biochemical and morphological characterization of growth and differentiation of normal human neonatal keratinocytes in a serum-free medium. J. Cell. Physiol. 134, 229-237.

Okubo, K., Karashima, T., Hachisuka, H. and SASAI, Y. (1989). Effect of KOLT-2 (CD28) MoAb on $\mathrm{T}$-cell proliferation induced by interleukins. In Leukocyte Typing IV, ed. Knapp,W., Dorken, B. and Gilks, W.R., pp. 355-357. Oxford: Oxford University Press.

Streilein, J. W. (1983). Skin-associated lymphoid Tissues (SALT): Origins and Function. J. Invest. Dermatol. 80, 125-175.

Su, H., Reano, A., Viac, J. and Thivolet, J. (1989). Comparative expression of bullous pemphigoid antigens in normal human epidermis and cultured keratinocytes. Clin. Immunol. Immunopathol. 51, 406-413.

Sugita, Y., Nagatani, T. and Ikezawa, Z. (1988). Gammainterferon modulates the expression of Ia antigen, pemphigus and pemphigoid antigens on PAM 212 cell. Proc. Jpn. Soc. Invest. Dermatol. 12, 100-101.

Tuernlund, U.M. (1978). Epidermal expression of HLA-DR antigens in mycosis fungoides. Arch. Dermatol. Res. 261, 81-86.

TJernlund, U.M. (1980). Ia-like antigens in lichen planus. Acta Dermatovener. 60, 309-314.

Wikner, N.E., Huff, J.C., Norris, D. A., Boyce, S.T., CARY, M., Kissinger, M. and Weston, W.L. (1986). Study of HLA-DR synthesis in cultured human keratinocytes. J. Invest. Dermatol. 87, 559-564.

YAAR, M., KARASSEK, R.L., SchnipPer, L.E. and Gilchrest, B.A. (1985). Effects of alpha and beta interferons on cultured human keratinocytes. J. Invest. Dermatol. 85, 70-74.

Yachie, A., Miyawaki, T., Uwadana, W., Ohzeki, S. and TANIGUChI, S. (1983). Sequential expression of $\mathrm{T}$ cell activation ( $\mathrm{Tac}$ ) antigen and Ia determinants on circulating human $\mathrm{T}$ cells after immunization with Tetanus toxid. J. Immunol. 131, 731-735. 